\title{
Ingestion of $\mathrm{Mn}$ and $\mathrm{Pb}$ by rats during and after pregnancy alters iron metabolism and behavior in offspring
}

\section{Citation}

Molina, Ramon M., Siripan Phattanarudee, Jonghan Kim, Khristy Thompson, Marianne Wessling-Resnick, Timothy J. Maher, and Joseph D. Brain. 2011. "Ingestion of Mn and Pb by Rats During and after Pregnancy Alters Iron Metabolism and Behavior in Offspring." NeuroToxicology 32 (4) (August): 413-422. doi:10.1016/j.neuro.2011.03.010.

\section{Published Version}

doi:10.1016/j.neuro.2011.03.010

\section{Permanent link}

http://nrs.harvard.edu/urn-3:HUL.InstRepos:30085122

\section{Terms of Use}

This article was downloaded from Harvard University's DASH repository, and is made available under the terms and conditions applicable to Other Posted Material, as set forth at http:// nrs.harvard.edu/urn-3:HUL.InstRepos:dash.current.terms-of-use\#LAA

\section{Share Your Story}

The Harvard community has made this article openly available.

Please share how this access benefits you. Submit a story.

Accessibility 


\title{
Ingestion of $\mathrm{Mn}$ and $\mathrm{Pb}$ by rats during and after pregnancy alters iron metabolism and behavior in offspring
}

\author{
Ramon M. Molinaa ${ }^{a}$ Siripan Phattanarudee ${ }^{b,{ }^{*}}$, Jonghan Kimc, Khristy Thompson ${ }^{c}$, Marianne \\ Wessling-Resnick ${ }^{\mathrm{c}}$, Timothy J. Maher ${ }^{\mathrm{b}}$, and Joseph D. Brain ${ }^{\mathrm{a}}$ \\ a Program in Molecular and Integrative Physiological Sciences, Department of Environmental \\ Health, Harvard School of Public Health, 665 Huntington Avenue, Boston, MA 02115 \\ ${ }^{b}$ Department of Pharmaceutical Sciences, Massachusetts College of Pharmacy and Health \\ Sciences, 179 Longwood Avenue, Boston, MA 02115 \\ c Department of Genetics and Complex Diseases, Harvard School of Public Health, 665 \\ Huntington Avenue, Boston, MA 02115
}

\begin{abstract}
Manganese $(\mathrm{Mn})$ and lead $(\mathrm{Pb})$ exposures during developmental period can impair development by direct neurotoxicity or through interaction with iron metabolism. Therefore, we examined the effects of maternal ingestion of $\mathrm{Mn}$ or $\mathrm{Pb}$ in drinking water during gestation and lactation on iron metabolism as well as behavior in their offspring. Pregnant dams were given distilled water, 4.79 $\mathrm{mg} / \mathrm{ml} \mathrm{Mn}$, or $2.84 \mathrm{mg} / \mathrm{ml} \mathrm{Pb}$ in drinking water during gestation and lactation. Pups were studied at time of weaning for ${ }^{59} \mathrm{Fe}$ absorption from the gut, duodenal Divalent Metal Transporter 1 (DMT1) expression, hematological parameters, and anxiety-related behavior using an Elevated Plus Maze (EPM) test. Metal-exposed pups had lower body weights and elevated blood and brain concentrations of the respective metal. $\mathrm{Pb}$-exposed pups had lower hematocrits and higher blood $\mathrm{Zn}$ protoporphyrin levels. In contrast, Mn exposed pups had normal hematological parameters but significantly reduced $\mathrm{Zn}$ protoporphyrin. Pharmacokinetic studies using ${ }^{59} \mathrm{Fe}$ showed that intestinal absorption in metal-exposed pups was not different from controls, nor was it correlated with duodenal DMT1 expression. However, intravenously injected ${ }^{59} \mathrm{Fe}$ was cleared more slowly in $\mathrm{Pb}$-exposed pups resulting in higher plasma levels. The overall tissue uptake of ${ }^{59} \mathrm{Fe}$ was lower in Mn-exposed and lower in the brain in Pb-exposed pups. The EPM test demonstrated that Mnexposed, but not $\mathrm{Pb}$-exposed, pups had lower anxiety-related behavior compared to controls. We conclude that gestational and lactational exposures to $\mathrm{Mn}$ or $\mathrm{Pb}$ differentially alter Fe metabolism and anxiety-related behavior. The data suggest that perturbation in Fe metabolism may contribute to the pathophysiologic consequences of $\mathrm{Mn}$ and $\mathrm{Pb}$ exposure during early development.
\end{abstract}

\footnotetext{
(C) 2011 Elsevier B.V. All rights reserved.

Corresponding Author: Ramon M. Molina, Harvard School of Public Health, Department of Environmental Health, 665 Huntington Avenue, Boston, MA 02115, Phone: 617-432-2311, Fax: 617-432-4710, rmolina@ @sph.harvard.edu.

Current address: Department of Pharmacy Practice, Faculty of Pharmaceutical Sciences, Chulalongkorn University, Phayathai Rd. Pathumwan, Bangkok 10330 Thailand

Competing financial interests declaration: The authors declare that there are no competing financial interests.

Publisher's Disclaimer: This is a PDF file of an unedited manuscript that has been accepted for publication. As a service to our customers we are providing this early version of the manuscript. The manuscript will undergo copyediting, typesetting, and review of the resulting proof before it is published in its final citable form. Please note that during the production process errors may be discovered which could affect the content, and all legal disclaimers that apply to the journal pertain.
} 


\section{Keywords}

neurotoxicity; biomarker; heavy metals; iron metabolism; anxiety; metal interaction

\section{INTRODUCTION}

Neurodevelopment begins in utero and continues throughout the postnatal period. This period of rapid development is highly susceptible to metal toxicity. Neurocognitive deficits caused by $\mathrm{Mn}$ or $\mathrm{Pb}$ exposure during developmental period have been reported in humans and animals. Cognitive deficits in $\mathrm{Pb}$-exposed children were demonstrated by lower intelligence quotient (IQ) scores (Al-Saleh et al., 2009, Coscia et al., 2003, Dietrich et al., 1991). $\mathrm{Pb}$ exposure may also contribute to attention deficit hyperactivity disorder (ADHD) (Brondum, 2009). Animal studies have reported comparable changes in cognitive and behavioral functions following $\mathrm{Pb}$ exposure. Exposure of rats to $\mathrm{Pb}$ during gestation (Yang et al., 2003), or during both gestation and lactation (Kuhlmann et al., 1997), led to long-term cognitive deficits in adult offspring. In addition, they found that animals exposed during both gestation and lactation via the mother showed significant behavioral effects even when tested as adults, when tissue $\mathrm{Pb}$ levels had returned to control values. In contrast, animals exposed only after weaning failed to demonstrate behavioral alterations despite elevated tissue $\mathrm{Pb}$ levels (Kuhlmann, McGlothan, 1997).

Increases in biomarkers of $\mathrm{Mn}$ exposure in humans such as hair manganese concentration have been associated with learning disabilities, hyperactivity, and attention deficits (Barlow, 1983, Collipp et al., 1983). It is known that in adults, high Mn exposure produces behavioral changes, such as emotional lability, memory loss, aggressive behavior, impairments in attention, as well as tremor, bradykinesia, postural deficits, and dystonia. In contrast to the adult brain, neonatal and growing brains are more susceptible to Mn toxicity. Absorption of Mn from the gut is generally high in the first weeks of life, followed by a steady decrease with age (Cawte, 1985). Moreover, excretion of Mn is minimal during the first 18 days of life (Cawte, 1985). These factors contribute to the considerably greater risk of neurotoxicity for neonates when exposed to excess Mn. The behavioral effects of Mn during early development are not fully characterized. Tran et. al used passive avoidance and burrowing detour tests to examine the effects of $\mathrm{Mn}$ in rats dosed by gavage during the first 21 days. No significant behavioral effects were reported (Tran et al., 2002b). In another study with rat pups similarly exposed to Mn, no effects on the Elevated Plus maze (EPM) and Morris water maze tests even at $10 \mathrm{mg} / \mathrm{ml} \mathrm{MnCl}_{2}$ exposure level were found (Pappas et al., 1997).

Several transport mechanisms for $\mathrm{Mn}, \mathrm{Pb}$ and $\mathrm{Fe}$ as well as other divalent metals have been identified and reviewed recently (Au et al., 2008). Divalent metal transporter-1 (DMT1) is the major transporter for $\mathrm{Pb}, \mathrm{Mn}$, and $\mathrm{Fe}$ (Garrick et al., 2003). Iron status modulates expression of DMT1 via transcriptional and/or post-transcriptional regulation (Chung and Wessling-Resnick, 2003). While early development constitutes a critical period of susceptibility to $\mathrm{Pb}$ or $\mathrm{Mn}$ neurotoxicity, there is also evidence and concern that metal uptake can be altered by iron deficiency. Mn uptake into the brain has been shown to be increased by iron deficiency (Aschner and Aschner, 1991, Thompson et al., 2007) while dietary Fe overload diminishes Mn accumulation in the brain (Aschner and Aschner, 1990, Mena et al., 1974). It has also been reported that $\mathrm{Pb}$ and $\mathrm{Cd}$ exposure increased DMT1 protein expression in the CNS of growing rats (Gu et al., 2009). During development, the uptake of Fe into the rat brain increases sharply after birth, peaks at postnatal day (PND) 15, and decreases thereafter (Taylor and Morgan, 1990). The finding that common pathways for metal absorption such as that mediated by DMT1 exist predicts that the pattern of DMT1's expression could impact the pharmacokinetics and thus the toxic effects of $\mathrm{Mn}$ or $\mathrm{Pb}$ 
exposures. Several studies have examined the influence of iron status on $\mathrm{Mn}$ or $\mathrm{Pb}$ neurotoxicity. However, the effects of exposure to $\mathrm{Mn}$ or $\mathrm{Pb}$ on iron metabolism are not fully understood. Maternal exposures of rat dams to high levels of $\mathrm{Mn}$ in diet during lactation results in increase in $\mathrm{Mn}, \mathrm{Cr}$ and $\mathrm{Zn}$ and decrease in Fe brain levels associated with higher DMT1 protein expression in various regions of the brain (Garcia et al., 2006). But whether the altered $\mathrm{Fe}$ and other essential metal levels result from changed DMT1 activity in the brain or in the gut is unknown. Pb effects on iron metabolism have been reported.

Offspring of iron-replete dams exposed to $3 \% \mathrm{~Pb}$ acetate in food and $0.2 \%$ in drinking water were intravenously injected with Tf-bound ${ }^{59} \mathrm{Fe}$. The results showed no effects on brain and kidney iron uptake and enhanced uptake in the liver (Crowe and Morgan, 1996).

Therefore, the effects of gestational and lactational $\mathrm{Mn}$ or $\mathrm{Pb}$ exposures on Fe metabolism in young pups are not fully understood. This is a critical time period when $\mathrm{Mn}$ and $\mathrm{Pb}$ neurotixicity occur as well as an important window for neural development and high iron demand. While studies have examined the effects of these metals on brain development and brain iron transport, their effects on iron transport in the gut and clearance from the blood is unclear. Both of these factors would contribute to the overall amount of metal available for use by the CNS. The relationship between $\mathrm{Mn}$ or $\mathrm{Pb}$ exposure, iron status, and behavioral effects has not been established. More information is needed on the molecular mechanisms involved. We predict that $\mathrm{Mn}$ and $\mathrm{Pb}$ will alter iron status. In this study we evaluated the offspring of $\mathrm{Mn}$ and $\mathrm{Pb}$ exposed dams for 1) disruptions in iron metabolism such as altered iron status, ZPP, ${ }^{59} \mathrm{Fe}$ kinetics, and intestinal DMT1 regulation, and 2) neurobehavioral outcomes, using anxiety-related responses in an EPM test.)

\section{METHODS}

\subsection{Animals}

The Institutional Animal Care and Use Committee at Harvard Medical School and at the Massachusetts College of Pharmacy and Health Sciences (MCPHS) approved protocols used in this study. Sexually mature male (10 wks old, $\sim 300 \mathrm{~g}$ ) and female (8 wks old, $\sim 220-240$ g) Sprague-Dawley rats were purchased from Charles River Laboratories (Wilmington, MA) and housed at the MCPHS animal facilities $\left(68-70^{\circ} \mathrm{F}, 50 \%\right.$ humidity, 12-hour light/dark cycle with lights off at $7 \mathrm{PM}$ ). The rats were allowed to acclimate to the facility for at least 2 days prior to starting the experiment. Animals had ad libitum access to in-house reverse osmosis (RO) deionized water and food (Purina Rodent Lab Chow \# 5001). The diet, drinking water solutions and $\mathrm{RO}$ water were analyzed for $\mathrm{Mn}$ or $\mathrm{Pb}$ by inductively-coupled mass spectroscopy (ICP-MS).

\subsection{Manganese and lead}

Manganese (II) chloride tetrahydrate (molecular weight $197.91 ; 98 \pm \%$, A.C.S. reagent) and lead (II) acetate trihydrate (molecular weight $379.33 ; 99 \pm \%$, A.C.S. reagent) were obtained from Sigma Aldrich (Allentown, PA). The metal solutions were prepared as needed with reverse-osmosis (RO) deionized water, every 2-3 days.

\subsection{Experimental design}

Mating of rats (1 male: 2 females) was conducted overnight in standard polycarbonate cages. Females were examined daily after cohabitation for the presence of sperm in the vaginal tract. The observation of a sperm-positive smear was considered evidence of successful mating and the day was designated gestation day 1 (GD 1). The sperm-positive females were then individually housed, and were exposed to metals via the drinking water. Presumed pregnant dams were randomly assigned to the following exposure groups $(\mathrm{n}=3$ dams/group) from GD 1 until postnatal day 24 (PND 24): 1) RO water (control), 2) $4.79 \mathrm{mg} /$ 
$\mathrm{ml} \mathrm{Mn}$, or 3) $2.84 \mathrm{mg} / \mathrm{ml} \mathrm{Pb}$ in RO water. Offspring were culled to 12 per dam at PND 2 with as close to an equal male to female ratio as possible. At PND 24, 8 pups/dam (4 males and 4 females) were tested using the EPM apparatus. At PND 25, ${ }^{59} \mathrm{Fe}$ absorption kinetics, intestinal expression of DMT1, and tissue levels of $\mathrm{Mn}$ and $\mathrm{Pb}$ and hematological parameters were studied in the same pups and the rest of the litters.

\subsection{Elevated Plus Maze (EPM) tests}

Anxiety-related responses were evaluated in 24 pups/group at PND 24 using the EPM. The apparatus consisted of 2 opposing open arms $(31.5 \mathrm{~cm} \times 10 \mathrm{~cm})$ and 2 opposing enclosed arms $(31.5 \mathrm{~cm} \times 10 \mathrm{~cm} \times 15 \mathrm{~cm})$. These arms extended from a central platform of $10 \mathrm{~cm}^{2}$. The EPM, which was painted black, was elevated $30 \mathrm{~cm}$ above the floor. Pups were placed individually in the center of the apparatus facing an open arm and were allowed to freely navigate the maze for 5 minutes. The EPM was cleaned with $70 \%$ alcohol before testing each rat, and all EPM testing was done between 1 and 4 PM. Arm entries were counted when more than half of the rat body entered the arm. A video-tracking system (Ethovision Data Acquisition Software v. 1.95, Noldus Information Technology, Sterling, VA) was used to record the movement of each pup within the maze. Parameters monitored were: latency of the first entry into the open arm (in sec), frequency of open arm entry (number of times in 5 $\mathrm{min}$ ), duration in open arms (as time and \%), and velocity ( $\mathrm{mm} / \mathrm{sec}$ ).

\subsection{Pharmacokinetics of ${ }^{59} \mathrm{Fe}$}

At PND 25, after the EPM experiment was performed, the same pups and the rest in the litters were used to determine the effects of maternal exposure to $\mathrm{Mn}$ or $\mathrm{Pb}$ on $\mathrm{Fe}$ metabolism. We sought to determine if iron absorption in the gut, blood clearance and tissue distribution are affected in metal-exposed pups. ${ }^{59} \mathrm{FeCl}_{3}$ was purchased from Perkin Elmer (Boston, MA) and diluted with 1:50 molar excess of ascorbic acid immediately prior to the experiment to reduce ${ }^{3+} \mathrm{Fe}$ to ${ }^{2+} \mathrm{Fe}$. A total of 12 pups from each group (4/dam) were dosed by gavage with ${ }^{59} \mathrm{Fe}$ in this buffer at $1.5 \mathrm{ml} / \mathrm{kg}$ volume dose and equivalent radiation dose of $150 \mu \mathrm{Ci}{ }^{59} \mathrm{Fe} / \mathrm{kg}$. Each pup was anesthetized with up to $4 \%$ vaporized isoflurane (Halocarbons Lab, North Augusta, SC) prior to gavage dosing. Blood samples were sequentially obtained from the tail vein over a 24-hour period $(5,13,30,60,90,120,240$, $480,1440 \mathrm{~m}$ ). Plasma and red blood cells were separated for radioisotope analysis. Since the blood levels of ${ }^{59} \mathrm{Fe}$ represent the amount absorbed from the gut minus the amount cleared from the circulation, another set of 12 pups/group was intravenously injected with the same dose of ${ }^{59} \mathrm{Fe}$ via the tail vein. Blood samples were similarly obtained from the contra-lateral tail vein over a 24 -hour period. At 4 or 24 hours post-dosing with ${ }^{59} \mathrm{FeCl}_{3}, 6$ pups/group were humanely killed with overdose of isoflurane anesthesia, exsanguinated via the abdominal aorta, and tissue samples collected. The gastrointestinal tract (GIT) was divided into segments after removal of the luminal contents. Radioactivity of samples of tissue, plasma, and red blood cells was measured using a WIZARD 1410 gamma counter (Perkin Elmers, Waltham, MA). Data were analyzed and expressed as tissue concentration $(\mu \mathrm{Ci} / \mathrm{g})$ and $\%$ of dose. At the end of the experiment, duodenal scrapings were collected from each pup for DMT1 analyses. Separate blood samples from remaining pups were taken for $\mathrm{Zn}$ protoporphyrin (ZPP) measurements.

\subsection{Pharmacokinetic analysis}

Only five blood samples of approximately $100 \mu \mathrm{L}$ each were taken from each pup to minimize blood loss and changes in hematocrit. All pups were sampled at 5 min postdosing. In order to generate a continuous blood profile over 24-hour period, each experimental group was divided into two subgroups, one including pups sampled up to $4 \mathrm{~h}$, and the other group sampled up to $24 \mathrm{~h}$. The pups within each subgroup were then ranked, in decreasing order of plasma ${ }^{59} \mathrm{Fe}$ level at the earliest sampling time $(5 \mathrm{~min})$, in both the 4-h 
and 24-h subgroups. The ranked pups from each subgroup were combined to generate "sets" that consisted of the 9 sampling points up to $24 \mathrm{~h}$. Pharmacokinetic (PK) analyses were performed for each set to compare PK parameters for ${ }^{59} \mathrm{Fe}$ among three exposure groups using the WinNonlin Software version 5.2 (Pharsight Corp, Mountain View, CA). PK parameters such as half-life (time during which $1 / 2$ of ${ }^{59} \mathrm{Fe}$ dose is cleared from the plasma), total area under the plasma concentration-time curve (AUC) (an estimate of ${ }^{59} \mathrm{Fe}$ in the plasma), total body clearance (CL) (rate of loss of ${ }^{59} \mathrm{Fe}$ from the body), and bioavailability (F) (the extent of absorption of ${ }^{59} \mathrm{Fe}$ from the gut) were calculated. Half-life was calculated as 0.693 divided by the slope of the regression line between 4 and 24 hours from a plot of the natural $\log$ of ${ }^{59} \mathrm{Fe}$ plasma concentration vs. time. A non-compartmental analysis was performed to quantify the degrees of exposure and loss of iron in the pups. AUC was calculated by the trapezoidal rule-extrapolation method. CL was computed by dividing the administered dose by AUC (Kim et al., 1997). F was then calculated as the ratio of AUC post-gavage to AUC post-IV injection.

\subsection{Tissue metal analyses}

After the ${ }^{59} \mathrm{Fe}$ kinetics experiments, the whole blood and one half (left side) of the brain samples used for radioactivity measurements were analyzed for $\mathrm{Mn}$ and $\mathrm{Pb}$ concentrations. Samples were weighed and nitric acid (OmniTrace Ultra High Purity, EM Science, Kansas City, MO) was added to the samples that were then digested overnight in a clean room hood after which they were diluted with deionized water. Analyses were performed by ICP/MS (Inductive Coupled Plasma-Mass Spectrometry: Elan-6100 DRC, Perkin-Elmer, Waltham, MA). Calibrations with external standards were run each day of measurement.

\subsection{Western blot analysis of duodenal membrane protein}

The proximal duodenal sections from each pup used in the ${ }^{59} \mathrm{Fe}$ kinetics experiment were rinsed with $2 X$ protease inhibitors (Complete Mini; Roche Diagnostics, Indianapolis, IN) diluted in PBS. Then a duodenal scraping was collected in an Eppendorf tube and snap frozen in liquid nitrogen. The scrapings were homogenized on ice in ice-cold breaking buffer (20 mM HEPES, pH 7.4, $100 \mathrm{mM} \mathrm{KCl,} 85 \mathrm{mM}$ sucrose, $20 \mu \mathrm{M}$ EGTA, pH 8.0) containing $2 \mathrm{X}$ protease inhibitor. After centrifugation at $3,500 \mathrm{rpm}$ at $4^{\circ} \mathrm{C}$ for $10 \mathrm{~min}$, supernatant fractions were centrifuged at $95,000 \mathrm{rpm}$ at $4^{\circ} \mathrm{C}$ for $10 \mathrm{~min}$. The resulting pellet was washed and resuspended in breaking buffer. Triton $\mathrm{X}-100$ was added to a final concentration of $1 \%$, and samples were gently rotated at $4^{\circ} \mathrm{C}$ for $1 \mathrm{~h}$ to solubilize membrane proteins. After further centrifugation at $95,000 \mathrm{rpm}$ at $4^{\circ} \mathrm{C}$ for $10 \mathrm{~min}$, the detergentsolubilized protein fraction was collected in the supernatant. Twenty $\mu \mathrm{g}$ of solubilized duodenal membrane proteins were electrophoresed on a 10\% SDS-polyacrylamide gel and transferred to Immobilon-Fl polyvinylidene difluoride membrane (Millipore, Billerica, MA) in SDS-free transfer buffer (20 mM Tris, $150 \mathrm{mM}$ glycine, $20 \%$ methanol). The membrane was blocked in Tris-buffered saline (TBS; $50 \mathrm{mM}$ Tris, $150 \mathrm{mM} \mathrm{NaCl}, \mathrm{pH}$ 7.4) containing $5 \%$ nonfat dry milk and incubated in rabbit anti-DMT1 antibody (a gift of Dr. Philippe Gros, McGill University, Montreal, QC, Canada) diluted 1:1,000 in TBS containing 1\% nonfat dry milk. The immunoblot was also incubated with mouse anti-Na/K ATPase (DAKO North America) diluted 1:20,000 in the same buffer as a loading control for the membrane protein preparation. There were no statistical differences in $\mathrm{Na} / \mathrm{K}$ ATPase levels among the three exposure groups, validating its use in these experiments. Immunoreactive proteins were visualized and quantified using a LI-COR Odyssey Infrared Imaging System with secondary antibodies goat anti-rabbit IR800 and goat anti-mouse IR680 (LI-COR Biosciences, Lincoln, $\mathrm{NE}$ ). DMT1 levels were normalized to the constitutively-expressed membrane protein $\mathrm{Na} / \mathrm{K}$ ATPase. 


\subsection{Non-heme iron and ZPP analyses}

Aliquots of liver and the other half of the brain (right side) were analyzed for non-heme iron (NHI) using the method of Torrance and Bothwell (Torrance and Bothwell, 1968) and calculated as $\mu \mathrm{g} \mathrm{Fe} / \mathrm{g}$ of wet tissue. ZPP was measured in selected blood samples at the Children's Hospital Department of Laboratory Medicine (Boston, MA) and expressed as $\mu \mathrm{mol} / \mathrm{g}$.

\subsection{Statistical analyses}

Body weights, blood and brain metal concentrations, and EPM data were analyzed using mixed effects regression models to estimate differences in exposure while accounting for sex effects and dam-to-dam variability in outcomes (Fitzmaurice GM et al., 2004).

Specifically, we included exposure group $(\mathrm{C}, \mathrm{Mn}, \mathrm{Pb})$ and pup sex as fixed effects and dam as a random effect in the model. This approach has the advantage of providing hypothesis tests of exposure effects that account for dam-to-dam variability, or equivalently litter effects, in an outcome. For the continuous outcomes we used linear mixed effects models whereas for the discrete frequency outcome (total frequency in open arms), we used an overdispersed Poisson mixed effects model. We employed a Bonferroni correction to account for multiple pair-wise tests among the three exposure groups. Data analyses were performed with PROC MIXED procedure using SAS statistical analysis software: SAS Institute, Cary, NC). The Western blot, pharmacokinetic parameters for ${ }^{59} \mathrm{Fe}$ and other hematological parameters were analyzed using analysis of variance (ANOVA) followed by Bonferroni post hoc using SPSS (Statistical Package for the Social Sciences, version 17, SPSS Inc., Chicago, IL). In all statistical tests, $P$ values $<0.05$ were considered significant.

\section{RESULTS}

\subsection{Effects of ingestion of $\mathrm{Mn}$ or $\mathrm{Pb}$ in drinking water on dams and pups}

For exposure studies, $\mathrm{Mn}(4.79 \mathrm{mg} / \mathrm{ml} \mathrm{Mn})$ and $\mathrm{Pb}(2.84 \mathrm{mg} / \mathrm{ml} \mathrm{Pb})$ in drinking water were provided to dams during pregnancy and lactation. These concentrations were selected based on published data (Brockel and Cory-Slechta, 1999a, Dorman et al., 2000, Lasley and Gilbert, 2000, Pappas, Zhang, 1997) and reflected the maximum doses tolerated by the dams. ICP-MS analysis of the LabDiet 5001 Rodent chow showed that it contains $59 \mu \mathrm{g} / \mathrm{g}$ $\mathrm{Mn}$ and $0.17 \mu \mathrm{g} / \mathrm{g} \mathrm{Pb}$. The amount of ingested $\mathrm{Mn}$ and $\mathrm{Pb}$ from rat chow was estimated as $2.9 \mathrm{mg} / \mathrm{kg} /$ day $\mathrm{Mn}$ and $0.008 \mathrm{mg} / \mathrm{kg} /$ day $\mathrm{Pb}$ based on average food consumption $(50 \mathrm{~g} / \mathrm{kg} /$ day) (Waynforth and Flecknell, 1992). The amounts in the diet were far lower than the calculated $\mathrm{Mn}$ and $\mathrm{Pb}$ ingested via drinking water and did not to contribute significantly. The estimated amounts of $\mathrm{Mn}$ and $\mathrm{Pb}$ consumed by the dams each day based on the measured daily intake of metal-containing water is shown in Table 1 . There were timedependent increases in the amounts of metal consumed daily for both $\mathrm{Mn}$ and $\mathrm{Pb}$.

Metal levels in drinking water solutions were determined by of ICP-MS. The mean Mn concentrations in RO water, $\mathrm{Mn}$ and $\mathrm{Pb}$ solutions were $0.00049,4790.1$, and $15.05 \mu \mathrm{g} / \mathrm{ml}$, respectively. The mean $\mathrm{Pb}$ levels in $\mathrm{RO}$ water, $\mathrm{Mn}$ and $\mathrm{Pb}$ solutions were 0.00003, 7.12, and $2838 \mu \mathrm{g} / \mathrm{ml}$, respectively. Since there were trace amounts of $\mathrm{Mn}$ and $\mathrm{Pb}$ in the $\mathrm{RO}$ water, control dams were estimated to have ingested $0.000078 \pm 0.000003 \mathrm{mg} \mathrm{Mn} / \mathrm{kg} /$ day during gestation, and $0.000186 \pm 0.000012 \mathrm{mg} \mathrm{Mn} / \mathrm{kg} /$ day during lactation. However, these levels were several orders of magnitude lower than Mn consumed by the Mn-exposed dams during gestation $(564.54 \pm 36.25 \mathrm{mg} \mathrm{Mn} / \mathrm{kg} / \mathrm{d})$ and lactation $(1255.65 \pm 61.21 \mathrm{mg} \mathrm{Mn} / \mathrm{kg} / \mathrm{d})$ (Table 1). Similarly, the control and Mn-exposed dams ingested far lower amounts of $\mathrm{Pb}$ from drinking water. Control dams were estimated to have ingested $0.000005 \pm 0.0000002 \mathrm{mg}$ $\mathrm{Pb} / \mathrm{kg} /$ day during gestation, and $0.00001 \pm 0.0000007 \mathrm{mg} \mathrm{Pb} / \mathrm{kg} /$ day during lactation. The $\mathrm{Pb}$-exposed dams during gestation were estimated to have ingested $342.57 \pm 28.11 \mathrm{mg} \mathrm{Pb} /$ 
$\mathrm{kg} /$ day, and $744.47 \pm 29.24 \mathrm{mg} \mathrm{Pb} / \mathrm{kg} /$ day during lactation (Table 1 ). The daily water intake was significantly reduced in the metal-exposed dams. During lactation, the daily intakes of RO water or metal-containing water increased $118-133 \%$ compared to during gestation, as a result of the increased fluid needed for adequate milk production.

The average body weights of the dams at the end of gestation or lactation period were not different, except for the Mn-exposed dams at the end of lactation (Table 1). No overt toxicity due to $\mathrm{Mn}$ or $\mathrm{Pb}$ exposures during gestation was observed in the dams. For example, the gestational term of Mn-exposed ( $22 \pm 0$ days) or Pb-exposed (21.3 \pm 0.3 days) dams was similar to that of the control group ( $21.7 \pm 0.3$ days). Litter size was also not significantly affected by metal exposure. Average litter sizes were $13 \pm 2$ (control), $13 \pm 1$ (Mn-exposed), and $14 \pm 1$ (Pb-exposed). There were no visually overt teratogenic effects in the offspring. However, the weight gain of pups from both $\mathrm{Mn}$ - and $\mathrm{Pb}$-exposed dams was significantly lower from birth until the end of the experiments (Figure 1). At PND 25, the body weight of pups exposed to $\mathrm{Mn}$ and $\mathrm{Pb}$ was $43 \%$ and $33 \%$ lower than that of the control pups, respectively $(\mathrm{P}<0.05)$. The characteristics of pups at PND 25 are summarized in Table 2.

\subsection{Effects on blood and brain metal concentrations}

Tissue $\mathrm{Mn}$ and $\mathrm{Pb}$ concentrations were determined by ICP-MS and are shown in Table 2. Statistical analyses using the mixed effects regression models to estimate differences in exposure while accounting for sex effects and dam-to-dam variability showed no significant sex nor dam differences in metal concentrations in blood and brain. It showed that maternal $\mathrm{Mn}$ ingestion resulted in significant five-fold increase in blood (14.5 \pm 0.5 to $75.6 \pm 6.6 \mathrm{ng}$ $\mathrm{Mn} / \mathrm{g})$ and a three-fold increase in brain $(434.9 \pm 5.3$ to $1278.5 \pm 49.4 \mathrm{ng} \mathrm{Mn} / \mathrm{g}) \mathrm{Mn}$ in the pups. $\mathrm{Pb}$ ingestion also resulted in a very large increase in blood (5.4 \pm 0.8 to $698.1 \pm 78.2$ $\mathrm{ng} \mathrm{Pb} / \mathrm{g})$ and brain $(16.4 \pm 5.6$ to $1006.2 \pm 73.9 \mathrm{ng} \mathrm{Pb} / \mathrm{g}) \mathrm{Pb}$ in the pups. Interestingly, the blood and brain $\mathrm{Pb}$ concentrations in Mn-exposed pups were also significantly elevated. $\mathrm{Pb}$ was present in the RO water, rat chow, and in the Mn drinking water possibly as contaminant of the $\mathrm{Pb}$ acetate. Thus, Mn-exposed dams ingested some $\mathrm{Pb}$ from drinking water although at a much lower levels than the Pb-exposed dams (Table 1). Likewise, $\mathrm{Mn}$ was also detectable in $\mathrm{RO}$ water, chow, and the $\mathrm{Pb}$ water. But the $\mathrm{Pb}$ brain and blood concentrations in the $\mathrm{Pb}$-exposed pups were not different from controls. Since both blood and brain metal concentrations for each pup were available, these data were analyzed by regression analysis. Blood metal concentrations may serve as a biomarker for brain $\mathrm{Mn}$ or $\mathrm{Pb}$ retention, and also reflect metal exposure. Blood and brain metal concentrations of pups within each exposure group were analyzed. A significant correlation was found between blood and brain Mn (Figure 2A) but not $\mathrm{Pb}$ (Figure 2B). Our data also showed that the brain had a 10-fold higher Mn concentration than the blood.

\subsection{Effects on iron status}

We measured hematocrits and found significantly lower levels in Pb-exposed but not $\mathrm{Mn}$ exposed pups (Table 2). Non-heme iron levels in both the liver and brain were not significantly different in either metal-exposed versus control groups. We found that blood levels of zinc protoporphyrin (ZPP) were elevated in $\mathrm{Pb}$-exposed pups as expected (Labbe et al., 1999). Interestingly, ZPP levels were significantly decreased in the Mn-exposed pups (Table 2).

The effects of gestational and lactational $\mathrm{Mn}$ or $\mathrm{Pb}$ exposure on iron metabolism were examined by determining the kinetics of ${ }^{59} \mathrm{Fe}$ absorption from the gut, the disposition of absorbed ${ }^{59} \mathrm{Fe}$, as well as the tissue distribution of ${ }^{59} \mathrm{Fe}$ at 4 and 24 hours after administration. The plasma concentrations of ${ }^{59} \mathrm{Fe}$ expressed as a percent of administered dose after IV injection or after gavage are shown in Figure 4. The plasma concentrations 
of ${ }^{59} \mathrm{Fe}$ declined bi-exponentially post-IV injection (Figure 4A) with no significant difference in mean half-lives among the three groups (data not shown). Clearance of ivinjected ${ }^{59} \mathrm{Fe}$ from the blood was significantly decreased in $\mathrm{Pb}$-exposed pups, resulting in greater circulating ${ }^{59} \mathrm{Fe}$ shown as higher AUC (dose fraction $\times$ min) than in the control group (Table 3). Mn exposure did not alter iron clearance from the blood. After gavage administration, ${ }^{59} \mathrm{Fe}$ was rapidly absorbed into the systemic circulation and disappeared exponentially (Figure 4B). These data suggest that $\mathrm{Pb}$-exposure increased plasma levels of ${ }^{59} \mathrm{Fe}$ regardless of whether ${ }^{59} \mathrm{Fe}$ was injected or gavaged. Intestinal ${ }^{59} \mathrm{Fe}$ absorption was not influenced by $\mathrm{Pb}$ or $\mathrm{Mn}$ exposure.

The tissue concentrations of ${ }^{59} \mathrm{Fe}$ at 4 and 24 hours were determined and were corrected for radioactive decay. At both time points, the tissue levels of ${ }^{59} \mathrm{Fe}$ in metal-exposed pups were generally lower than control values except for plasma. Tissue concentrations of ${ }^{59} \mathrm{Fe}(\mu \mathrm{Ci} / \mathrm{g})$ at 4 hours are summarized in Table 4. Compared to controls, ${ }^{59} \mathrm{Fe}$ concentrations in the brain, lungs, spleen and small intestine of the Mn-exposed pups were significantly lower in the IV-injected group. The lung and spleen levels in $\mathrm{Pb}$-exposed pups were also lower but the plasma level was significantly higher than in controls. After gavage, the kidneys, bone marrow, spleen, and small intestine ${ }^{59} \mathrm{Fe}$ concentrations in the Mn-exposed pups were also lower than control values. Table 5 shows a similar pattern of ${ }^{59} \mathrm{Fe}$ tissue concentrations at 24 hours. Compared to control values, tissue concentrations of IV-injected ${ }^{59} \mathrm{Fe}$ in the $\mathrm{Mn}$ exposed pups were generally lower than control (bone marrow, skeletal muscle and spleen). Similarly, after gavage, ${ }^{59} \mathrm{Fe}$ concentrations in plasma, bone marrow, skeletal muscle, liver, spleen, and large intestine of the Mn-exposed pups were also significantly lower than in controls (Table 4). In contrast, only the plasma level was significantly higher in $\mathrm{Pb}$-exposed pups after ${ }^{59} \mathrm{Fe}$ IV injection.

\subsection{Effects on anxiety-related behavior}

Consequences of gestational and lactational exposure to $\mathrm{Mn}$ and $\mathrm{Pb}$ were evaluated in the EPM test. Behavioral responses observed included the latency of the first occurrence to the open arm, frequency of open arm entry, and duration in open arms (as time and percentage). These parameters were used as an index of anxiety/anti-anxiety behavior (Pellow et al., 1985). Using the same mixed effects regression models to estimate EPM differences among exposure groups while accounting for sex effects and dam-to-dam variability, we found no significant sex nor dam effect in all EPM parameters. The analyses showed that pups from $\mathrm{Mn}$-exposed but not from $\mathrm{Pb}$-exposed dams had significant decreases in latency to enter an open arm, increased frequency of open arm entries, and increased overall time spent in the open arms (as duration in open arm, time and \%). Figure 3 shows combined data for males and female pups.

\subsection{Effects on intestinal DMT1 expression}

Western blot analyses examined the effects of gestational and lactational exposure to $\mathrm{Mn}$ or $\mathrm{Pb}$ on the expression of DMT1 in the duodenum. The ratios of DMT1 to Na/K ATPase signals are summarized in Figure 5. We found that pups exposed to Mn had increased duodenal expression of DMT1 protein while $\mathrm{Pb}$ exposure did not affect DMT1 levels.

\section{DISCUSSION}

We conducted this study to evaluate the effects of maternal ingestion of $\mathrm{Pb}$ or $\mathrm{Mn}$ via drinking water on their offspring at the time of weaning. We hypothesized that these metals may also exert their neurobehavioral effects indirectly through altering iron status, a well known cause of neurobehavioral dysfunction (Lozoff et al., 1991). All analyses were performed at the time of weaning to identify early effects of in utero and lactational 
exposure to metals. We designed the exposure to include both gestation and lactation since these periods represent critical windows for $\mathrm{Mn}$ and $\mathrm{Pb}$ neurotoxicity. The concentrations of $\mathrm{Pb}(2.84 \mathrm{mg} / \mathrm{ml})$ or $\mathrm{Mn}(4.79 \mathrm{mg} / \mathrm{ml})$ selected were within the ranges reported to increase tissue metal levels and impair behavior in animal studies (Brockel and Cory-Slechta, 1999b, Dorman, Struve, 2000, Lasley and Gilbert, 2000, Pappas, Zhang, 1997). Although these doses were higher than likely human exposure, no overt toxicity was observed in pregnant dams as evidenced by normal gestational term and litter size. No teratogenic effects were noted. However, the weights of Mn-exposed dams were significantly lower at the end of lactation, an indication of some toxic effects of this oral dose of Mn (Table 1). The body weights of Pb-exposed dams were not different from controls despite their similar reduced water consumption (Table 1). More significant effects on body weights were observed in pups of both metal-exposed groups. For Mn, this weight effects may relate to Mn disruptive effects on thyroid hormone homeostasis (Soldin and Aschner, 2007).

Both $\mathrm{Pb}$ and $\mathrm{Mn}$ translocated to the pups during in utero and lactation periods. Metal concentrations in the blood and brain of pups were all elevated compared to their controls. Although the placental or milk levels of $\mathrm{Mn}$ or $\mathrm{Pb}$ were not measured, the transfer of $\mathrm{Mn}$ across the placenta and the excretion of $\mathrm{Mn}$ into milk was previously demonstrated (Dorman et al., 2005a). Dorman et al. (Dorman et al., 2005b) showed that exposure to inhaled $\mathrm{MnSO}_{4}$ $\left(0.5\right.$ and $\left.1 \mathrm{mg} \mathrm{Mn} / \mathrm{m}^{3}\right)$ during gestation ( $6 \mathrm{hr} /$ day, 7 days/week) increased Mn level in the placenta, and increased Mn levels in the brains and lungs of the dams. Kontur and Fechter (1985) reported elevated forebrain and hindbrain Mn concentrations in newborn rats, whose dams were exposed to high levels of $\mathrm{MnCl}_{2}$ in their drinking water (5 and $10 \mathrm{mg} \mathrm{MnCl}_{2} /$ $\mathrm{mL}$ ) throughout gestation. The excretion of $\mathrm{Mn}$ into the milk was evidenced by the increased $\mathrm{Mn}$ level in the milk of lactating dams exposed to a high dose $\mathrm{MnSO}_{4}\left(1 \mathrm{mg} \mathrm{Mn} / \mathrm{m}^{3}\right)$ by inhalation (Dorman, McElveen, 2005a). Milk collected on PND18 from dams exposed to $\mathrm{MnSO}_{4}\left(1 \mathrm{mg} \mathrm{Mn} / \mathrm{m}^{3}\right)$ had Mn concentrations that were significantly higher than controls. The availability of both blood and brain metal concentrations for each pup allowed for additional regression analyses. This is useful since blood metal concentrations may serve as a biomarker for brain $\mathrm{Mn}$ or $\mathrm{Pb}$ retention, and also metal exposure. A significant correlation was found between blood and brain $\mathrm{Mn}$ but not for $\mathrm{Pb}$. The difference perhaps is due to the fact that $\mathrm{Mn}$ is a nutrient and is normally regulated, while $\mathrm{Pb}$ has no known biological role in metabolism and may be sequestered into depot sites in peripheral tissues (e.g., bone).

In utero and lactational transport of $\mathrm{Pb}$ has been previously reported in rats (Rodrigues et al., 1996). $\mathrm{Pb}$ was undetectable in the brain of day-old pups although present in the blood. By $\mathrm{PND} 23, \mathrm{~Pb}$ accumulated in the blood, kidneys and cerebral cortex. In addition, this study measured the $\mathrm{Pb}$ levels in milk from the stomach contents of 1-day-old rats. The $\mathrm{Pb}$ levels in the milk of $\mathrm{Pb}$-exposed rats were significantly higher than those in controls confirming that $\mathrm{Pb}$ is excreted into the milk. The relative contribution of gestational versus lactational exposure to metal tissue levels could not be determined with our experimental design since pups were exposed during both developmental periods. Unpublished data from our laboratory showed that the percent transport of ${ }^{54} \mathrm{Mn}$ to the pups relative to maternal dose during lactation (PND 21) was approximately twice of that during gestation (PND 1). Our data suggest that $\mathrm{Pb}$ and $\mathrm{Mn}$ transport and/or clearance rates were different, since retained $\mathrm{Pb}$ (130-fold in blood, 60-fold in brain) was much higher than Mn (5-fold in blood, 3-fold in brain) relative to control. Interestingly, $\mathrm{Pb}$ transport appears to be influenced by $\mathrm{Mn}$ since pups from Mn-exposed dams had significant elevations of blood (2.5-fold) and brain (1.3fold) $\mathrm{Pb}$ levels, suggesting in vivo interaction between $\mathrm{Mn}$ and $\mathrm{Pb}$. This may be due to the fact that Mn and Pb share at least one transporter, DMT1 (Garrick, Dolan, 2003). The precise pathways of $\mathrm{Pb}$ and $\mathrm{Mn}$ transport via the placenta or the uptake and secretion from the mammary glands into the milk are unknown. That DMT1 may be involved is suggested 
by the presence of DMT1 in the placenta and in the mammary gland epithelium (Garrick et al., 2006, McArdle et al., 2008).

Elevated levels of $\mathrm{Mn}$ in the brain were associated with behavioral responses indicative of lessened anxiety. In the EPM experiment, observed tasks of shorter latency of first entry into an open arm, an increased frequency of open arm entries, and increased duration of time spent in the open arms indicate anti-anxiety behavior (Walf and Frye, 2007). It has been reported that rats with less anxiety or disinhibition control tended to have shorter latency of first entry into an open arm, and also spend more time in the open arms, perceived as danger zones (Ueno et al., 2002, Walf and Frye, 2007). Several theories have been proposed as underlying mechanisms responsible for this behavior. Frontostriatal systems have been implicated in response inhibition. Alterations within this region are thought to produce impulsivity associated with a number of psychological disorders (Itami and Uno, 2002, Jentsch and Taylor, 1999). Abnormalities in ventral region of the frontal lobes, such as the orbitofrontal cortex have also been observed in ADHD (Hesslinger et al., 2002, Itami and Uno, 2002). Subcortical structures dysfunction within the basal ganglia may account for some of the deficits in impulse control observed in the ADHD children (Vaidya et al., 1998). In addition, there is evidence that dopamine alterations are important in ADHD syndrome such as in dopamine transporter (DAT) (Dougherty et al., 1999), dopamine decarboxylase activity (Ernst et al., 1998), and dopamine $\mathrm{D}_{4}$ receptor gene polymorphism (LaHoste et al., 1996).

Despite the greater increase in brain $\mathrm{Pb}$ concentration over control, $\mathrm{Pb}$-exposed pups exhibited no change in anxiety-related EPM parameters. These negative findings are in agreement with previous reports. The effects of $\mathrm{Pb}$ on behavior determined by the EPM have shown mixed results. Trombini et al. (Trombini et al., 2001) reported that exposure to 750 $\mathrm{ppm}$ of $\mathrm{Pb}$ acetate in drinking water during pregnancy and lactation had no effect on the behavior determined by the EPM. In contrast, Moreira et al. (Moreira et al., 2001) reported that developmental exposure to $\mathrm{Pb}$ at $500 \mathrm{ppm}$ (during pregnancy and lactation) caused higher anxiety-related behavior, as shown by the animals' increased aversion to the open arms. Decreased anxiety in Mn-exposed rats in our results were in agreement with some (Tran et al., 2002a) but not with other reports (Kern et al., 2010, Pappas, Zhang, 1997, Reichel et al., 2006). Several factors may contribute to these discrepancies, such as exposure parameters and age of testing, as well as differences in the testing apparatus used. Both Mnand $\mathrm{Pb}$-exposed pups displayed slower velocities consistent with effects on locomotor functions reported earlier for $\mathrm{Mn}$ (St-Pierre et al., 2001) and Pb (Moreira et al., 2001).

Iron deficiency has been shown to reduce motor activity and produce anxiety-related behaviors (Beard et al., 2002). Since Mn or Pb may disrupt Fe metabolism by molecular mimicry, we examined the influence of gestational and lactational exposures on iron status. $\mathrm{Mn}$ and $\mathrm{Pb}$ had different effects on iron status. Total brain non-heme iron content was unaffected, although it is possible that specific regions of the brain were affected by metal exposure. $\mathrm{Pb}$ exposure did result in low hematocrit accompanied by elevated ZPP. ZPP is a product of iron-deficient erythropoiesis, and is a normal metabolite formed from heme biosynthesis. Since $\mathrm{Pb}$ competes with $\mathrm{Fe}$, the stoichiometric balance shifts so that more $\mathrm{Zn}$ than Fe is incorporated into the protoporphyrin ring. Hence, increased ZPP levels are often used as a biomarker to detect lead poisoning in children (Labbe, Vreman, 1999). As expected, ZPP was elevated in $\mathrm{Pb}$-exposed pups. Mn exposure did not change most hematological parameters except for a significant reduction in ZPP. This suggests that the presence of excess Mn may exert a similar effect; perhaps MnPP is formed at the expense of ZPP. Ferrochetalase, the enzyme that inserts iron or zinc into the protoporphyrin ring is known to be competitively inhibited by Mn (Dailey, 1987). Moreover, Mn can be non- 
catalytically chelated by protoporphyrin (Verger et al., 1983). Further studies to explore blood ZPP as a potential biomarker of Mn exposure are warranted.

$\mathrm{Gu}$ et al. (Gu, Chen, 2009) have reported that exposures to $\mathrm{Pb}$ and cadmium synergistically increases DMT1 protein expression in the CNS of developing rats. Since DMT1 is a common transporter for $\mathrm{Fe}, \mathrm{Mn}$ and $\mathrm{Pb}$, we examined whether gestational and lactational exposure to $\mathrm{Mn}$ or $\mathrm{Pb}$ modulates DMT1 in the duodenum that may alter ${ }^{59} \mathrm{Fe}$ absorption kinetics. Intestinal DMT1 expression was elevated in Mn-exposed pups but the gut absorption of Fe was not significantly altered. Since Fe and Mn are competitively transported by DMT1, the lack of correlation between intestinal DMT1 expression and Fe absorption in Mn-exposed pups could in part be explained by competitive inhibition of $\mathrm{Fe}$ absorption by ingested Mn from the milk despite elevated DMT1 level in the gut.

$\mathrm{Pb}$ exposure did not affect DMT1 or influence ${ }^{59} \mathrm{Fe}$ absorption from the gut and thus most likely does not affect the observed changes in hematocrit via perturbed iron intake. However, ${ }^{59} \mathrm{Fe}$ injected directly into the circulation was cleared more slowly, and thus was retained to a greater extent in $\mathrm{Pb}$-exposed than in control pups. Although ${ }^{59} \mathrm{Fe}$ persisted longer in the plasma, its uptake in most tissues of $\mathrm{Pb}$-exposed pups was generally not different from control. These observations are consistent with interference of $\mathrm{Fe}$ incorporation into heme by $\mathrm{Pb}$, resulting in slower clearance of ${ }^{59} \mathrm{Fe}$ from the plasma and the consequential anemia that was observed.

\section{CONCLUSIONS}

In toto, our data indicate that gestational and lactational exposure to $\mathrm{Mn}$ and $\mathrm{Pb}$ alters iron metabolism and behavior in offspring in different ways. Mn exposure resulted in reduced plasma and brain ${ }^{59} \mathrm{Fe}$ levels, and associated decreased locomotor activity and anxietyrelated behavior. It also resulted in decreased ZPP and enhanced duodenal DMT1 expression. These results suggest that excess Mn alters Fe metabolism resulting in an upregulation of DMT1. Mn may also interfere with iron homeotasis by replacing iron in key enzymes or inhibiting enzymes essential in iron metabolism. The resulting increase in brain $\mathrm{Mn}$ and decreased iron uptake most likely contributed to the decreased anxiety-related behavior in the developing rat. $\mathrm{Pb}$ exposure did not change ${ }^{59} \mathrm{Fe}$ absorption from the gut nor DMT1 expression. However, ${ }^{59} \mathrm{Fe}$ stayed longer in the circulation leading to increased plasma, but decreased brain ${ }^{59} \mathrm{Fe}$ levels. $\mathrm{Pb}$ exposure also caused anemia with increased $\mathrm{ZPP}$, and associated decreased locomotor activity. These data suggest that $\mathrm{Pb}$ exposure results in decreased iron incorporation into red blood cells. Even with sufficient dietary iron, $\mathrm{Pb}$ excess, causes anemia. This concomitant anemia would result in decreased oxygenation of vital organs, especially the brain, and may exacerbate $\mathrm{Pb}$ toxicity. Taken together, $\mathrm{Mn}$ and $\mathrm{Pb}$ exposure each interferes with iron homeostasis that may exacerbate their neurobehavioral effects. Additional studies to elucidate iron homeostatic pathways specifically disrupted by $\mathrm{Mn}$ and $\mathrm{Pb}$ exposure in neonates are warranted.

\section{Acknowledgments}

This work was supported by the National Institute of Environmental Health Sciences (NIEHS) [P01 ES012874, ES000002] and by the US Environmental Protection Agency (EPA) [RD-83172501]. The contents are solely the responsibility of the authors and do not necessarily represent the official views of the NIEHS or EPA. We also thank Brent Coull and Thomas Donaghey for help with statistical analyses, Swati Betharia and Marissa Kakoyiannis for technical assistance, and Melissa Curran for editorial advice. 


\section{References}

Al-Saleh I, Nester M, Mashhour A, Moncari L, Shinwari N, Mohamed Gel D, et al. Prenatal and postnatal lead exposure and early cognitive development: longitudinal study in Saudi Arabia. J Environ Pathol Toxicol Oncol. 2009; 28:283-302. [PubMed: 20102326]

Aschner M, Aschner JL. Manganese transport across the blood-brain barrier: relationship to iron homeostasis. Brain Res Bull. 1990; 24:857-60. [PubMed: 2372703]

Aschner M, Aschner JL. Manganese neurotoxicity: cellular effects and blood-brain barrier transport. Neurosci Biobehav Rev. 1991; 15:333-40. [PubMed: 1956602]

$\mathrm{Au}$ C, Benedetto A, Aschner M. Manganese transport in eukaryotes: the role of DMT1. Neurotoxicology. 2008; 29:569-76. [PubMed: 18565586]

Barlow PJ. A pilot study on the metal levels in the hair of hyperactive children. Med Hypotheses. 1983; 11:309-18. [PubMed: 6645998]

Beard JL, Erikson KM, Jones BC. Neurobehavioral analysis of developmental iron deficiency in rats. Behav Brain Res. 2002; 134:517-24. [PubMed: 12191838]

Brockel BJ, Cory-Slechta DA. The effects of postweaning low-level $\mathrm{Pb}$ exposure on sustained attention: a study of target densities, stimulus presentation rate, and stimulus predictability. Neurotoxicol. 1999a; 20:921-33.

Brockel BJ, Cory-Slechta DA. Lead-induced decrements in waiting behavior: involvement of D2-like dopamine receptors. Pharmacol Biochem Behav. 1999b; 63:423-34. [PubMed: 10418784]

Brondum J. Attention deficit hyperactivity disorder and blood lead levels in Chinese children. Environ Health Perspect. 2009; 117:A286. [PubMed: 19654893]

Cawte J. Psychiatric sequelae of manganese exposure in the adult, foetal and neonatal nervous systems. Aust N Z J Psychiatry. 1985; 19:211-7. [PubMed: 3910017]

Chung J, Wessling-Resnick M. Molecular mechanisms and regulation of iron transport. Crit Rev Clin Lab Sci. 2003; 40:151-82. [PubMed: 12755454]

Collipp PJ, Chen SY, Maitinsky S. Manganese in infant formulas and learning disability. Ann Nutr Metab. 1983; 27:488-94. [PubMed: 6651226]

Coscia JM, Ris MD, Succop PA, Dietrich KN. Cognitive development of lead exposed children from ages 6 to 15 years: an application of growth curve analysis. Child Neuropsychol. 2003; 9:10-21. [PubMed: 12815519]

Crowe A, Morgan EH. Interactions between tissue uptake of lead and iron in normal and irondeficient rats during development. Biol Trace Elem Res. 1996; 52:249-61. [PubMed: 8811282]

Dailey HA. Metal inhibition of ferrochelatase. Ann N Y Acad Sci. 1987; 514:81-6. [PubMed: 3442391]

Dietrich KN, Succop PA, Berger OG, Hammond PB, Bornschein RL. Lead exposure and the cognitive development of urban preschool children: the Cincinnati Lead Study cohort at age 4 years. Neurotoxicol Teratol. 1991; 13:203-11. [PubMed: 1710765]

Dorman DC, McElveen AM, Marshall MW, Parkinson CU, Arden James R, Struve MF, et al. Maternal-fetal distribution of manganese in the rat following inhalation exposure to manganese sulfate. Neurotoxicology. 2005a; 26:625-32. [PubMed: 16112325]

Dorman DC, McElveen AM, Marshall MW, Parkinson CU, James RA, Struve MF, et al. Tissue manganese concentrations in lactating rats and their offspring following combined in utero and lactation exposure to inhaled manganese sulfate. Toxicol Sci. 2005b; 84:12-21. [PubMed: 15601677]

Dorman DC, Struve MF, Vitarella D, Byerly FL, Goetz J, Miller R. Neurotoxicity of manganese chloride in neonatal and adult CD rats following subchronic (21-day) high-dose oral exposure. $\mathrm{J}$ Appl Toxicol. 2000; 20:179-87. [PubMed: 10797470]

Dougherty DD, Bonab AA, Spencer TJ, Rauch SL, Madras BK, Fischman AJ. Dopamine transporter density in patients with attention deficit hyperactivity disorder. Lancet. 1999; 354:2132-3. [PubMed: 10609822]

Ernst M, Zametkin AJ, Matochik JA, Jons PH, Cohen RM. DOPA decarboxylase activity in attention deficit hyperactivity disorder adults. A [fluorine-18]fluorodopa positron emission tomographic study. J Neurosci. 1998; 18:5901-7. [PubMed: 9671677] 
Fitzmaurice, GM.; Laird, NM.; JH, W. Applied Longitudinal Analysis. New York: John Wiley and Sons; 2004.

Garcia SJ, Gellein K, Syversen T, Aschner M. A manganese-enhanced diet alters brain metals and transporters in the developing rat. Toxicol Sci. 2006; 92:516-25. [PubMed: 16705042]

Garrick MD, Dolan KG, Horbinski C, Ghio AJ, Higgins D, Porubcin M, et al. DMT1: a mammalian transporter for multiple metals. Biometals. 2003; 16:41-54. [PubMed: 12572663]

Garrick MD, Singleton ST, Vargas F, Kuo HC, Zhao L, Knopfel M, et al. DMT1: which metals does it transport? Biol Res. 2006; 39:79-85. [PubMed: 16629167]

Gu C, Chen S, Xu X, Zheng L, Li Y, Wu K, et al. Lead and cadmium synergistically enhance the expression of divalent metal transporter 1 protein in central nervous system of developing rats. Neurochem Res. 2009; 34:1150-6. [PubMed: 19083094]

Hesslinger B, Tebartz van Elst L, Thiel T, Haegele K, Hennig J, Ebert D. Frontoorbital volume reductions in adult patients with attention deficit hyperactivity disorder. Neurosci Lett. 2002; 328:319-21. [PubMed: 12147334]

Itami S, Uno H. Orbitofrontal cortex dysfunction in attention-deficit hyperactivity disorder revealed by reversal and extinction tasks. Neuroreport. 2002; 13:2453-7. [PubMed: 12499848]

Jentsch JD, Taylor JR. Impulsivity resulting from frontostriatal dysfunction in drug abuse: implications for the control of behavior by reward-related stimuli. Psychopharmacology (Berl). 1999; 146:37390. [PubMed: 10550488]

Kern CH, Stanwood GD, Smith DR. Preweaning manganese exposure causes hyperactivity, disinhibition, and spatial learning and memory deficits associated with altered dopamine receptor and transporter levels. Synapse. 2010; 64:363-78. [PubMed: 20029834]

Kim J, Kim SH, Lee MG. Liver and gastrointestinal first-pass effects of azosemide in rats. J Pharm Pharmacol. 1997; 49:878-83. [PubMed: 9306255]

Kuhlmann AC, McGlothan JL, Guilarte TR. Developmental lead exposure causes spatial learning deficits in adult rats. Neurosci Lett. 1997; 233:101-4. [PubMed: 9350842]

Labbe RF, Vreman HJ, Stevenson DK. Zinc protoporphyrin: A metabolite with a mission. Clin Chem. 1999; 45:2060-72. [PubMed: 10585337]

LaHoste GJ, Swanson JM, Wigal SB, Glabe C, Wigal T, King N, et al. Dopamine D4 receptor gene polymorphism is associated with attention deficit hyperactivity disorder. Mol Psychiatry. 1996; 1:121-4. [PubMed: 9118321]

Lasley SM, Gilbert ME. Glutamatergic components underlying lead-induced impairments in hippocampal synaptic plasticity. Neurotoxicol. 2000; 21:1057-68.

Lozoff B, Jimenez E, Wolf AW. Long-term developmental outcome of infants with iron deficiency. N England J Med. 1991; 325:687-94. [PubMed: 1870641]

McArdle HJ, Andersen HS, Jones H, Gambling L. Copper and iron transport across the placenta: regulation and interactions. J Neuroendocrinol. 2008; 20:427-31. [PubMed: 18266949]

Mena I, Horiuchi K, et al. Factors enhancing entrance of manganese into brain: iron deficiency and age. J Nuc Med. 1974; 15:516.

Moreira EG, Vassilieff I, Vassilieff VS. Developmental lead exposure: behavioral alterations in the short and long term. Neurotoxicol Teratol. 2001; 23:489-95. [PubMed: 11711252]

Pappas BA, Zhang D, Davidson CM, Crowder T, Park GA, Fortin T. Perinatal manganese exposure: behavioral, neurochemical, and histopathological effects in the rat. Neurotoxicol Teratol. 1997; 19:17-25. [PubMed: 9088007]

Pellow S, Chopin P, File SE, Briley M. Validation of open:closed arm entries in an elevated plus-maze as a measure of anxiety in the rat. J Neurosci Methods. 1985; 14:149-67. [PubMed: 2864480]

Reichel CM, Wacan JJ, Farley CM, Stanley BJ, Crawford CA, McDougall SA. Postnatal manganese exposure attenuates cocaine-induced locomotor activity and reduces dopamine transporters in adult male rats. Neurotoxicol Teratol. 2006; 28:323-32. [PubMed: 16571372]

Rodrigues AL, Rocha JB, Mello CF, Souza DO. Effect of perinatal lead exposure on rat behaviour in open-field and two-way avoidance tasks. Pharmacol Toxicol. 1996; 79:150-6. [PubMed: 8884874]

Soldin OP, Aschner M. Effects of manganese on thyroid hormone homeostasis: potential links. Neurotoxicology. 2007; 28:951-6. [PubMed: 17576015] 
St-Pierre A, Normandin L, Carrier G, Kennedy G, Butterworth R, Zayed J. Bioaccumulation and locomotor effect of manganese dust in rats. Inhal Toxicol. 2001; 13:623-32. [PubMed: 11452358]

Taylor EM, Morgan EH. Developmental changes in transferrin and iron uptake by the brain in the rat. Brain Res Dev Brain Res. 1990; 55:35-42.

Thompson K, Molina RM, Donaghey T, Schwob JE, Brain JD, Wessling-Resnick M. Olfactory uptake of manganese requires DMT1 and is enhanced by anemia. Faseb J. 2007; 21:223-30. [PubMed: 17116743]

Torrance JD, Bothwell TH. A simple technique for measuring storage iron concentrations in formalinised liver samples. S African J Med Sci. 1968; 33:9-11.

Tran TT, Chowanadisai W, Crinella FM, Chicz-DeMet A, Lonnerdal B. Effect of high dietary manganese intake of neonatal rats on tissue mineral accumulation, striatal dopamine levels, and neurodevelopmental status. Neurotoxicol. 2002a; 23:635-43.

Tran TT, Chowanadisai W, Lonnerdal B, Le L, Parker M, Chicz-Demet A, et al. Effects of neonatal dietary manganese exposure on brain dopamine levels and neurocognitive functions. Neurotoxicol. 2002b; 23:645-51.

Trombini TV, Pedroso CG, Ponce D, Almeida AA, Godinho AF. Developmental lead exposure in rats: is a behavioral sequel extended at F2 generation? Pharmacol Biochem Behav. 2001; 68:743-51. [PubMed: 11526972]

Ueno KI, Togashi H, Mori K, Matsumoto M, Ohashi S, Hoshino A, et al. Behavioural and pharmacological relevance of stroke-prone spontaneously hypertensive rats as an animal model of a developmental disorder. Behav Pharmacol. 2002; 13:1-13. [PubMed: 11990715]

Vaidya CJ, Austin G, Kirkorian G, Ridlehuber HW, Desmond JE, Glover GH, et al. Selective effects of methylphenidate in attention deficit hyperactivity disorder: a functional magnetic resonance study. Proc Natl Acad Sci U S A. 1998; 95:14494-9. [PubMed: 9826728]

Verger C, Sassa S, Kappas A. Growth-promoting effects of iron- and cobalt- protoporphyrins on cultured embryonic cells. J Cell Physiol. 1983; 116:135-41. [PubMed: 6863396]

Walf AA, Frye CA. The use of the elevated plus maze as an assay of anxiety-related behavior in rodents. Nat Protoc. 2007; 2:322-8. [PubMed: 17406592]

Waynforth, HB.; Flecknell, PA. Experimental and surgical technique in the rat. 2. London: Academic Press; 1992.

Yang Y, Ma Y, Ni L, Zhao S, Li L, Zhang J, et al. Lead exposure through gestation-only caused longterm learning/memory deficits in young adult offspring. Exp Neurol. 2003; 184:489-95. [PubMed: 14637118] 


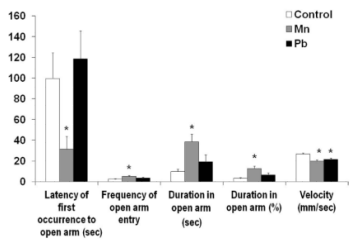

Figure 1. Weight of pups over time

The body weight of pups exposed to Mn (closed triangles) and $\mathrm{Pb}$ (closed circles) was significantly lower compared with control pups (closed squares) at all time points $(P<$ 0.05). At PND 25, the body weight of pups exposed to $\mathrm{Mn}$ and $\mathrm{Pb}$ was $43 \%$ and $33 \%$ lower than that of the control pups, respectively. Data are means \pm SE. $n=36 /$ group. 

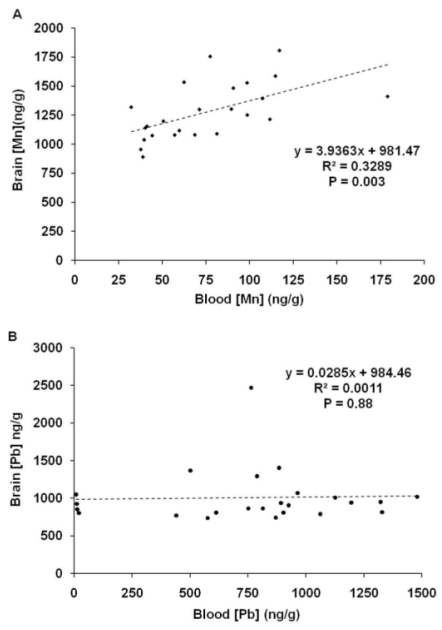

Figure 2. Correlation of blood to brain metal concentration

Scatter plot of individual brain and blood $\mathrm{Mn}(\mathrm{A})$ or $\mathrm{Pb}(\mathrm{B})$ levels. Regression analysis showed a significant correlation of brain to blood Mn concentration. $* \mathrm{P}<0.05$. 


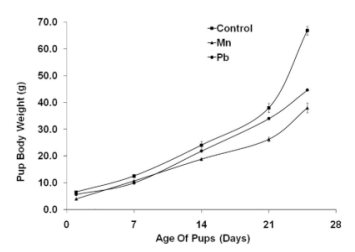

Figure 3. Behavioral changes in rat pups gestationally- and lactationally-exposed to $\mathrm{Mn}$ or $\mathbf{P b}$ Behavioral test was done on PND 24. Decreased anxiety-related behavior is associated with shortened latency of first open arm entry, frequency of open arm entries and duration of time spent in open arms. Higher average velocity reflects greater locomotor activity. Mn-exposed pups (gray bars) but not $\mathrm{Pb}$-exposed (black bars) displayed significant changes in parameters indicative of lower anxiety than control pups (white bars). Both $\mathrm{Mn}$ - and $\mathrm{Pb}$-exposed pups displayed lower overall velocities when compared with control pups. ${ }^{*} P<0.05$ compared with control. Data are means \pm SE. $n=24$ pups/group. 

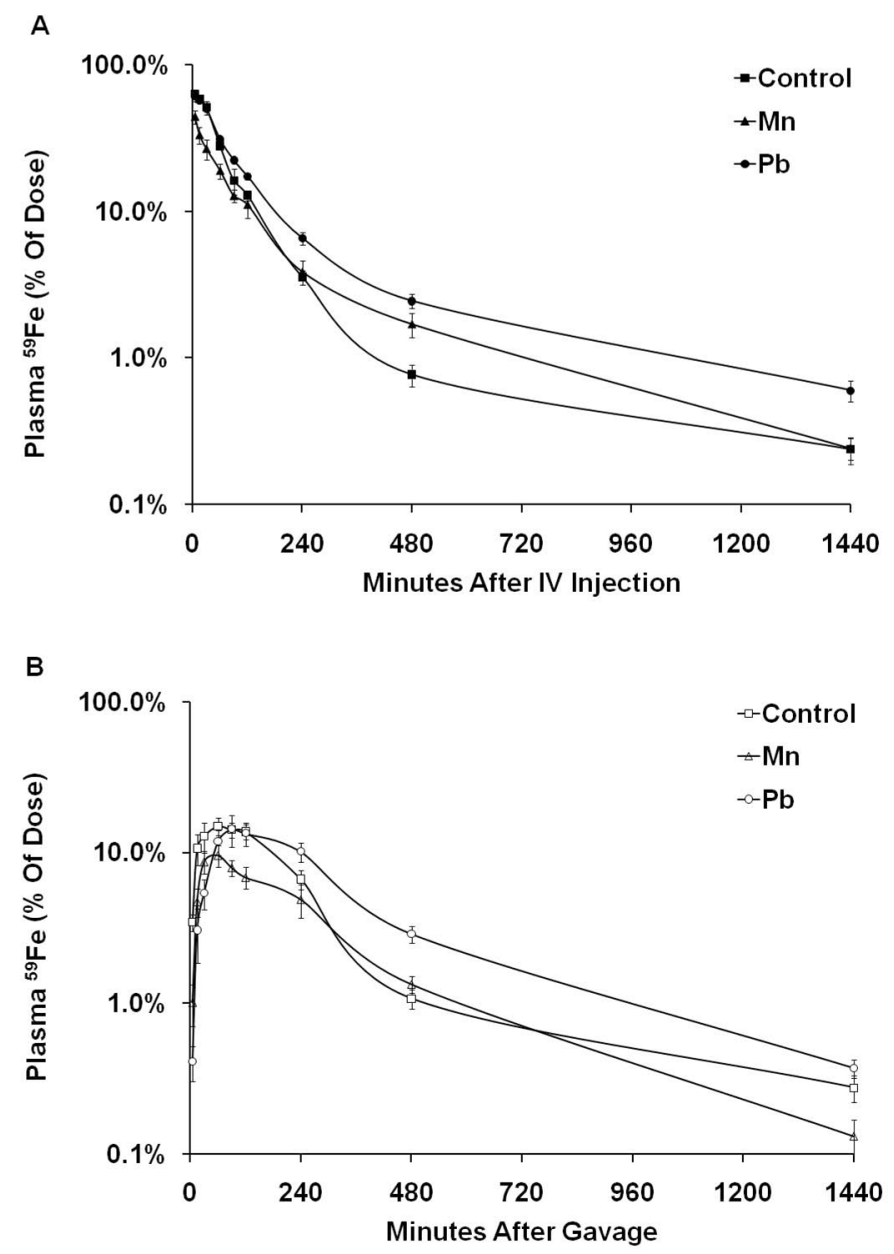

Figure 4. Plasma levels of ${ }^{59} \mathrm{Fe}$ following IV or gavage administration in pups Plasma levels of ${ }^{59} \mathrm{Fe}$ over $24 \mathrm{~h}$ period post-intravenous (A) and post-gavage (B) dosing of pups. Figure 4A - Control (closed squares), Mn-exposed (closed triangles), Pb-exposed (closed circles). Figure 4B - Control (open squares), Mn-exposed (open triangles), Pbexposed (open circles). Pharmacokinetic analyses of both gavage and IV data showed that the bioavailability (extent of absorption) and half-life were unchanged by metal exposure whereas $\mathrm{Pb}$-exposure significantly decreased ${ }^{59} \mathrm{Fe}$ elimination from the plasma after either IV or gavage administration (See Table 3 ). 
A
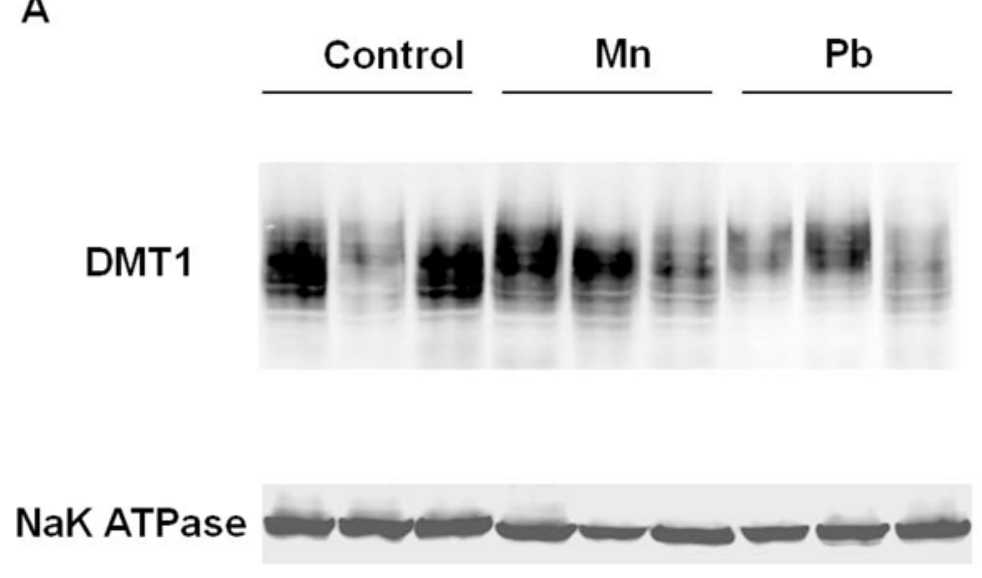

B

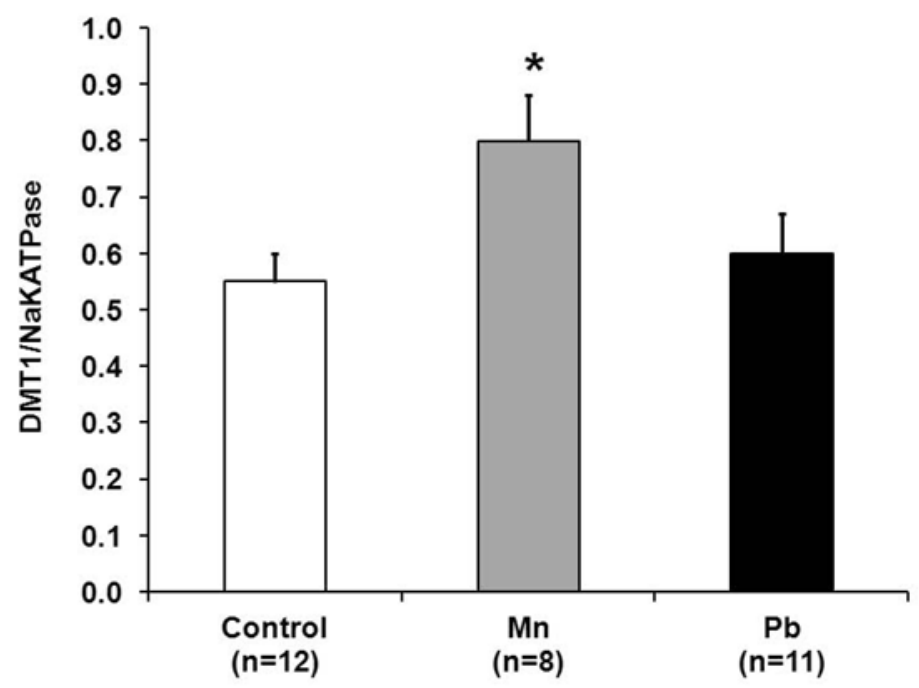

Figure 5. Western blot analysis of DMT1 in duodenal membrane fractions

DMT1 was visualized and quantified by using the LI-COR Odyssey Infrared Imaging System and the LI-COR secondary antibodies goat anti-rabbit IR800 and goat anti-mouse IR680 (LI-COR Biosciences, Lincoln, NE). Anti-DMT1 antibody was a gift of Dr. Philippe Gros (McGill University). Na/K ATPase was used as a membrane protein loading control and was detected in all duodenal samples. Shown in Figure 6A is a representative blot. Shown in Figure $6 \mathrm{~B}$ are means $\pm \mathrm{SE}$ of relative signal intensity ratio (DMT1/Na/K ATPase, $\mathrm{n}=12$ control, $8 \mathrm{Mn}$, and $8 \mathrm{~Pb}$ ). DMT1 was upregulated in Mn-exposed (gray bar) but not in $\mathrm{Pb}$-exposed pups (black bar). $* P<0.05$ compared with control. 


\section{Table 1}

Body weights and estimated $\mathrm{Mn}$ and $\mathrm{Pb}$ intake of dams from drinking water

\begin{tabular}{|c|c|c|c|}
\hline & Control $(n=3)$ & Mn-exposed (n=3) & Pb-exposed $(n=3)$ \\
\hline \multicolumn{4}{|c|}{ Weight $(\mathrm{g})$ at the end of } \\
\hline Gestation & $418.67 \pm 29.68$ & $354.00 \pm 7.57$ & $382.67 \pm 5.49$ \\
\hline Lactation & $342.33 \pm 8.57$ & $255.00 \pm 11.36^{*}$ & $335.00 \pm 12.10$ \\
\hline \multicolumn{4}{|c|}{ Water consumption ( $\mathrm{ml} / \mathrm{kg} /$ day) } \\
\hline Gestation & $155.75 \pm 6.40$ & $117.85 \pm 13.11^{*}$ & $120.58 \pm 9.91^{*}$ \\
\hline Lactation & $371.40 \pm 23.56$ & $262.14 \pm 12.78^{*}$ & $262.03 \pm 10.30^{*}$ \\
\hline \multicolumn{4}{|c|}{ Mn intake (mg/kg/day) } \\
\hline Gestation & $0.000078 \pm 0.000003$ & $564.54 \pm 36.25$ & $1.82 \pm 0.15$ \\
\hline Lactation & $0.000186 \pm 0.000012$ & $1255.65 \pm 61.21$ & $3.95 \pm 0.15$ \\
\hline \multicolumn{4}{|c|}{$\mathrm{Pb}$ intake $(\mathrm{mg} / \mathrm{kg} /$ day) } \\
\hline Gestation & $0.000005 \pm 0.0000002$ & $0.84 \pm 0.05$ & $342.57 \pm 28.11$ \\
\hline Lactation & $0.00001 \pm 0.0000007$ & $1.87 \pm 0.09$ & $744.47 \pm 29.24$ \\
\hline
\end{tabular}

$\mathrm{Mn}$ and $\mathrm{Pb}$ intake were estimated based on measured concentrations in drinking water using ICP-MS and measured water consumption.

${ }^{*} \mathrm{P}<0.05$ compared to control, $\mathrm{n}=3$ dams per group. 


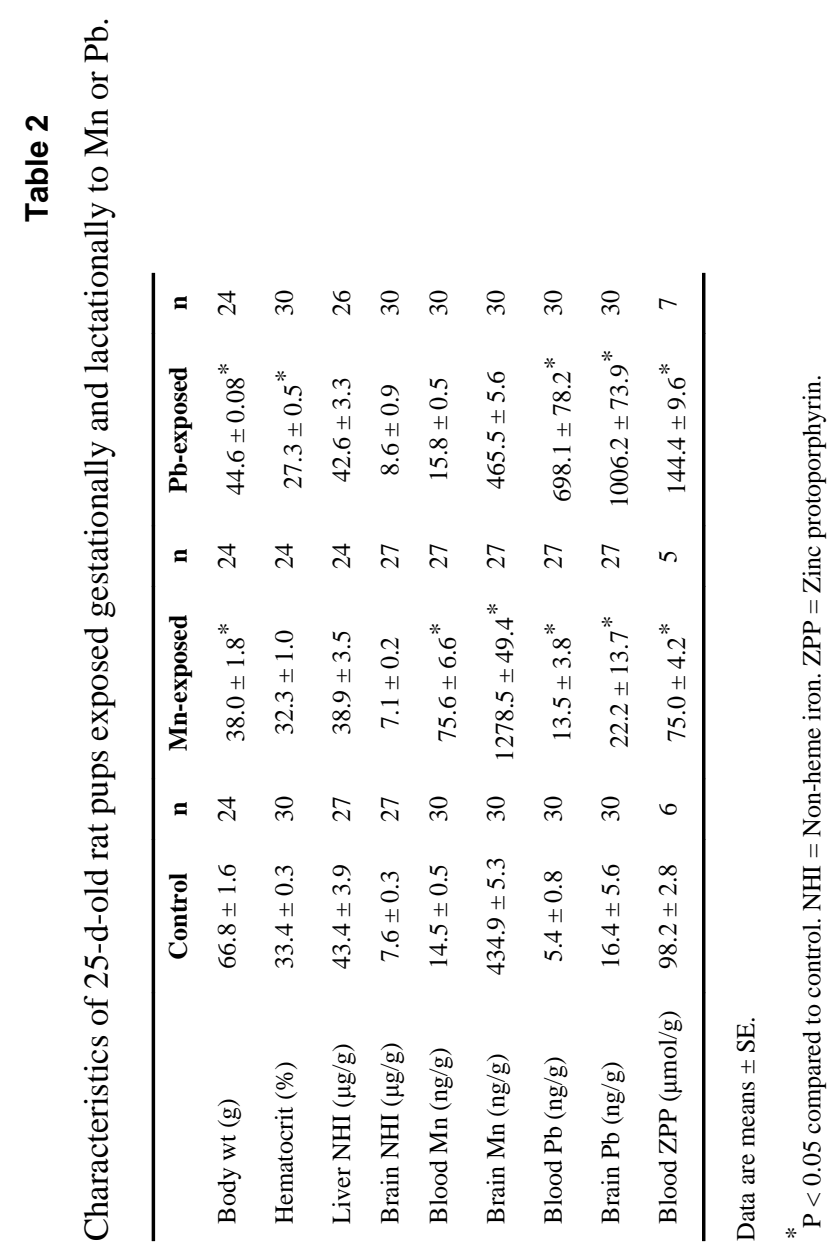


Table 3

Pharmacokinetic parameters of ${ }^{59} \mathrm{Fe}$ after intravenous or gavage administration of ${ }^{59} \mathrm{Fe}$ to rats exposed gestationally and lactationally to $\mathrm{Mn}$ or $\mathrm{Pb}$.

\begin{tabular}{lcll}
\hline Parameters (Unit) & Control & Mn-exposed & Pb-exposed \\
$\mathrm{AUC}_{\text {gavage }},($ dose fraction $\times \min )$ & $41.0 \pm 1.1$ & $27.7 \pm 3.8^{*}$ & $52.5 \pm 5.1$ \\
$\mathrm{AUC}_{\mathrm{iv}},($ dose fraction $\times \min )$ & $61.3 \pm 4.1$ & $50.3 \pm 6.5$ & $82.6 \pm 3.8^{*}$ \\
$\mathrm{~F},(\%)$ & $68.3 \pm 3.6$ & $55.6 \pm 5.7$ & $62.8 \pm 3.7$ \\
\hline
\end{tabular}

Derived from the IV and gavage data were AUC (area under the ${ }^{59} \mathrm{Fe}$ plasma concentration-time curve). F (bioavailability, the extent of absorption from the gut, $\mathrm{AUC}_{\text {gavage}} / \mathrm{AUC}_{\mathrm{iv}}$ ) was computed using both IV and gavage data. Data are means $\pm \mathrm{SE}$ ( $\left.\mathrm{n}=4-6 \mathrm{pups} / \mathrm{group}\right)$. ANOVA,

* $P<0.05$ compared with control. 
